\title{
THE PSYCHOLOGICAL ASPECTS OF INTENSIVE CARE UNITS
}

GUDRUN DANNENFELDT

B.Soc.Sc. (Nursing), Diploma Psychiatric Nursing

\section{OPSOMMING}

Die tegnologiese en fisiese versorging van pasiënte in ' $n$ intensiewe sorgeenheid is gewoonlik baie goed — die sielkundige aspekte van intensiewe verpleegsorg word egter dikwels verwaarloos.

Om die nodige ondersteuning te kan bied, moet die verpleegkundige bewus wees van pasiënte se sielkundige behoeftes, die verdedigingsmeganismes wat gebruik word, die invloed van spanning en ook van die aspekte in die eenheid wat tot sielkundige probleme by pasiënte bydra.

Die aard van die werk en verhoudings met kollegas in die intensiewe sorgeenheid kan ook sielkundige probleme by die verpleegpersoneel veroorsaak.

Enige sielkundige probleme in 'n intensiewe sorgeenheid, hetsy van pasiënte of personeel moet deurlopend geidentifiseer, geanaliseer en die oorsaak vasgestel word om sodoende die probleem te kan oplos.

\section{INTRODUCTION}

The technical and physical care of the critically ill patient has been perfected, but the psychological aspects of intensive nursing care have to a greater or lesser extent been neglected. The objective of this article is to highlight the causes of psychological problems in an intensive care unit, how to recognise these problems and above all how to prevent or correct them.

Nursing involves being a competent practitioner in the physical, social, and psychological care of the patient in the preventive, promotive, curative and rehabilitative spheres. This also applies to intensive nursing care. Giving physical care to the patient is not enough. the nurse must aiso promote psychological well-being and prevent psychological factors which may influence the patient adversely. When critically ill patients are first brought to the unit, they are too sick to be affected psychologically by the significance of the unit. Later emotional stress will be superimposed on the stress of the illness and this can result in psychotic or neurotic behaviour. The staff in the unit is however also constantly exposed to psychological stresses.

\section{HUMAN NEEDS}

Needs are basic requirements of the body and psyche which human beings require for health and survival. A need is a feeling of necess-

ity to remove, allay or correct conditions which are experienced as a disruption or deficiency of the self or environment. Maslow's hier-

archy of needs, their relevance in the intensive care unit and their nursing implications are shown in table 1 .

\section{TABLE 1 MASLOW'S HIERARCHY OF NEEDS, THEIR RELEVANCE IN THE INTENSIVE CARE UNIT AND IMPLICATIONS FOR NURSING (Johnson \& Davis (1975)}

\begin{tabular}{|c|c|c|}
\hline Needs & Relevance to ICU & Implications for nursing \\
\hline Physiological needs & $\begin{array}{l}\text { Needs to be met are } \\
\text { comfort, activity, nu- } \\
\text { trition, elimination of } \\
\text { wastes }\end{array}$ & $\begin{array}{l}\text { Patients are often not able to } \\
\text { fulfil these needs by them- } \\
\text { selves, nursing function is then } \\
\text { for example seeing to comfort } \\
\text { despite his being in traction, } \\
\text { determining intake and output } \\
\text { together with blood chemistry } \\
\text { to assess adequacy of intrave- } \\
\text { nous nutrition, and so on }\end{array}$ \\
\hline Safety needs & $\begin{array}{l}\text { Threat of injury by } \\
\text { person or machines }\end{array}$ & $\begin{array}{l}\text { Medication must be checked. } \\
\text { Machines must be in best } \\
\text { working condition }\end{array}$ \\
\hline Need to belong & $\begin{array}{l}\text { Security, means of } \\
\text { communication }\end{array}$ & $\begin{array}{l}\text { Staff must communicate with } \\
\text { the patient and patient must } \\
\text { be allowed to respond. } \\
\text { Patients need constant re- } \\
\text { assurance }\end{array}$ \\
\hline Need for recognition & $\begin{array}{l}\text { Esteem, dignity, re- } \\
\text { spect }\end{array}$ & $\begin{array}{l}\text { Patients must be treated with } \\
\text { respect and addressed cor- } \\
\text { rectly }\end{array}$ \\
\hline Need to create & $\begin{array}{l}\text { Expression of self, } \\
\text { need to contribute }\end{array}$ & $\begin{array}{l}\text { Patients must be involved in } \\
\text { the choice and implementation } \\
\text { of their treatment }\end{array}$ \\
\hline $\begin{array}{l}\text { Need to know and } \\
\text { understand }\end{array}$ & $\begin{array}{l}\text { Need for knowledge } \\
\text { and comprehension }\end{array}$ & $\begin{array}{l}\text { An explanation of diagnosis } \\
\text { and treatment on the } \\
\text { patient's level }\end{array}$ \\
\hline Self actualisation & Order, truth, privacy & $\begin{array}{l}\text { Patients should have as much } \\
\text { privacy as possible - pull } \\
\text { screens or close doors. The } \\
\text { patient has the right to be told } \\
\text { the truth }\end{array}$ \\
\hline
\end{tabular}

\section{Needs}


The staff must assess the needs of the patient. An attempt must be made to correct any disturbance and to maintain balance. The staff must also be alert to their own needs and ensure that they are adequately satisfied.

\section{STRESS}

Stress is the reaction of the body to stimulation which is dangerous enough to require the body to make an adjustment to overcome the danger. Stress affects the body by increasing the pulse rate or blood pressure, causing profuse sweating and could even result in stress ulcers.

Psychological manifestations are agitation, restlessness and the use of defence mechanisms. Stress in any form is due to one or more needs that are not satisfied.

\section{DEFENCE MECHANISMS}

The staff and patients unconsciously implement various defence mechanisms to protect themselves from stress. The two overt defences are fight and flight. Guilt and anxiety are controlled by hostile aggressive behaviour, destroying the source of danger or by running away from it. The critically ill patient cannot implement these mechanisms as they involve physical effort. There are also internal defences such as repression whereby inner conflicts are not allowed to reach consciousness or substitution by which one's efforts are directed to alternative goals. For example, the sister who cannot handle a patient will start shouting at nurses. Rationalisation is a defence mechanism whereby the person justifies his deficiencies to himself and others. In projection the person rejects his own feelings and attributes them to someone else. The depressed patient will repeatedly tell his visitors that they appear sad. Reaction formation is the denial of the conflict - no problem exists. Another defence mechanism often used is regression, which involves returning to more primitive forms of behaviour seen in patients who lie in the foetal position. Displacement occurs when minor discomforts assume importance. A good example of this is when patients develop a headache in order to receive attention.

\section{ICU PSYCHOSIS}

The term ICU psychosis or ICU syndrome is slowly finding its way into nursing literature. It develops after three to five days in the intensive care unit and according to Hackett et al (1968) $30 \%$ to $70 \%$ of patients in intensive care units develop this syndrome. The patient's personality and psychological make-up are predisposing factors in developing an ICU psychosis. A person suffering from depression pre-operatively will, for example, still be depressed post-operatively and similarly, an anxious person who has a myocardial infarct will retain his anxiety.

Other predisposing factors are the length of time under anaesthesia (8 to 10 hours) or on the cardiopulmonary bypass machine. The type of illness can also play a role it is easier to cope with a cholecystectomy or an asthma attack than with a colostomy.

The signs and symptoms of the syndrome are mild at first, presenting with sleeplessness and restlessness. The patient then becomes disorientated, frightened and often starts interfering with his treatment. This may be followed by perceptual distortions and illusions - seeing and hearing things that are not there. Patient's remarks and behaviour become inappropriate and they are unco-operative. These symptoms resolve after four to five days. According to Noble (1979) there is a higher mortality rate among patients who develop an $I C U$ psychosis than among those who do not.

The treatment for this syndrome is sedation with phenothiazines or discharge from the unit.

\section{CAUSES OF PSYCHOLOGI- CAL PROBLEMS IN PATIENTS}

Various factors in the intensive care unit itself can contribute to the psychological breakdown of patients and staff.

\section{Fear and anxiety}

The first factor which may cause the
ICU syndrome is the patient's fear and anxiety. These two are related and are the most frequently occurring manifestations of stress.

Most patients are afraid - afraid of the new environment, new people, his illness and its prognosis, in short, afraid of the unknown. The fear and anxiety could be apparent or not, but the patient's fears must be allayed. The patient must be told clearly what his illness entails, what surgery if any will be performed and what the prognosis is. It is debatable whether the known or the unknown produces more fear, but the patient has the right to be fully informed. Any questions must be answered as honestly as possible and the family should also be informed to prevent any misconceptions.

Where possible, the nurse and doctor from the intensive care unit should visit the patient in the ward before surgery, so that when the patient wakes up in the unit he sees a familiar face and is immediately reassured. The patient should also be shown around the unit and have the apparatus explained to him. These little things will not eradicate the patient's fear totally, but his anxiety will be reduced and thus not hinder his recovery unnecessarily. This is of course only possible with planned surgery.

Then there is the patient who arrives in an intensive care unit without initiation, for example. after an accident or myocardial infarct. The apparatus and procedures must none the less be explained to the patient. One can of course not go into as much detail as with cold cases, and additional reassurance is thus necessary.

\section{The unit}

The unit environment, is unpleasant. The lights are usually on 24 hours a day, there is constant noise and the patients lie fairly close together. This results in the patient getting very little rest and sleep and becoming exhausted. The constant light in the unit is necessary, although when possible. the lights should be dimmed at night. Once the patient's condition is stable. nursing should be modified to allow for sleep periods. Sleep is also essential for recovery. 
Staff should not lose sight of the impact of the unit on the patient and should make an effort to reduce the level of noise by not talking so loud or dropping things. Monitoring equipment could be kept outside the patient's cubicle. Some, however, like looking at their monitors, and about $50 \%$ are reassured by the monitor, according to Hackett et al (1968).

There is little privacy for the patient in the intensive care unit. There are curtains and screens, which are often not used as frequently as they should be. Even if they are drawn, they do not screen the area off totally and so participation in the other patients' care is inevitable

The patients feel exposed. They are never alone and there are always people watching everything they do. The sexes are mixed in the units and so patients lose their dignity. Staff should thus be as curteous and discreet as possible.

\section{Communication}

Patients in the intensive care unit are submitted to both sensory overstimulation and sensory deprivation - overstimulation by noise, light and new things, but deprivation through the lack of touch, spoken word and reassurance.

As mentioned before, the level of noise is increased considerably by the voices of the staff. Invariably the staff talk louder than is necessary to overtone other noises or to get rid of frustration. Noble (1979), breaks down the pattern of communication as follows:

- $65 \%$ of all communication is related to the patient's treatment and care. This usually occurs in medical jargon, short unconnected sentences or commands - $18 \%$ of the total communication is about personal affairs of the staff. This usually occurs during slack periods, but near the patient and not in the tea lounge where it belongs. This is not only unprofessional but can disturb the patients and even confuse them

- only $14 \%$ of the communication is directed at the patient. consisting mainly of short ex- changes of words or non-verbal communication.

To correct this situation the staff must control the quality and content of their conversation. They must direct more communication to the patient and discuss personal affairs at regular coffee breaks, away from the patient.

The doctors and nurses think they are doing the patient a favour by walking away from his bed to discuss the patient further. When reaching the next patient's bed, he hears glimpses of conversation about the first patient, but assumes they pertain to himself. Quite understandably the second patient becomes concerned about this new development in his illness.

The patient must be told what he wants to know and what the staff wants him to know. Anything else must be discussed far away from anyone else.

The staff also often make careless remarks, for example, I don't know how this works, let's hope this is right. Such remarks are fear provoking to the patient and certainly not encouraging.

\section{Security}

The patient is quite defenceless he is too sick to defend himself physically and can often not defend himself verbally either. He realises that he is totally vulnerable and thus regresses to childlike behaviour in order to overcome his feelings of helplessness. $50 \%$ of the patients become disorientated for time. This is due to days of unconsciousness, a long anaesthetic and constant daylight. Studies by Hackett (1968) show that most patients want a calendar that they can read. while only a few want a visible clock. It would also help the patient to regain his sense of time if the staff in conversation mentioned the time and the full date as well as the number of days the patient has been in the intensive care unit.

The patient becomes used to the attention and starts associating the close observation with security. He even becomes used to the noise and light. The patient realises that he will be discharged at some stage but his feelings are ambivalent and this becomes a point of anxiety: will the ward staff be able to look after him adequately? He will have to readjust to new people and surroundings. On the other hand, if all the other patients are discharged the one that stays behind begins to wonder why he did not go and why is he not getting better.

\section{Visitors}

Patients are allowed to have visitors for short periods. This is, however, a controversial point - visitors are important for the patient's wellbeing, but at the same time they may have a negative influence. Although there are nurses around most of the time, the patients are lonely and visitors help to prevent them from feeling isolated in the strange place. The visitors, mostly close relatives, often bring comforting news. On the other hand the patient is reminded of home and may start worrying: is everything all right, are they managing? and he begins to feel guilty about being in hospital. The patient may also try to impress the visitors by looking and acting healthier than he really is. Other patients may act a bit worse to get extra sympathy. Visitors generally tire the patient, adding to his fatigue and exhaustion. Therefore visitors should be encouraged, but restricted to two or three close relatives, visiting for short periods of five to ten minutes only.

These are only some of the apparent factors causing psychological problems in patients.

\section{FACTORS WHICH AFFECT THE STAFF}

Most nurses have at some stage of their career felt stagnant, bitter, disillusioned and have seen no future. They have done their work, but have put no feeling into it. This often happens when nurses eventually realise that things are not as they had expected them to be their ideals are not congruent with the reality. This apathetic state of the staff is not only detrimental to the patients but also to the person herself and other staff. To reach a situation where the work is more or less in line with the beliefs of the staff, the co-operation of the nurs- 
ing service is necessary - including adequate and functioning equipment, enough staff and good pay. The nurses want to be treated with respect and there must be mechanisms of discussing problems of medical incompetance with the doctors.

The nurses can do much to help themselves from becoming resigned in their work - outside activities, small goals that can be realised, a good spirit and as a final resort. change of job.

What factors in the intensive care unit make working there so stressful?

\section{Nature of the work}

One of the first aspects is the workload. Not only does the heavy workload tire the nursing staff physically but the responsibility, the vast array of knowledge that has to be at the fingertips, quick thinking and the need for constant alertness all contribute to mental strain.

The other point with regards to workload is the shortage of permanent staff. There are always new sisters and nurses who are frightened. but above all, do not know the work and the significance of the observations. This adds an extra burden for the sister in the unit. She not only has to care for a patient, but has to teach and help new staff. supervise them and anticipate problems.

Not only must the nurse be alert, she must be one step ahead. The staff is continuously doing potentially lifesaving tasks, one mistake could thus be fatal. This fact at the back of the nurse's mind makes her nervous. Therefore nursing staff must have a very good training and constantly keep up to date, so that mistakes occur as infrequently as possible.

The nurse finds herself in a dilemma if she has made a mistake. To admit it involves admitting ignorance or incompetance and so decreases her status with her colleagues. The mistake can however be corrected. If she does not admit her mistake, she will not lose face with her colleagues, but she will feel quilty and the mistake cannot be corrected. Either way there is psychological damage and it would be ideal if interpersonal relationships in a unit were such that colleagues would not be humiliated for making mistakes, but rather help prevent them by more support and teaching.

Furthermore, there is the constant threat of a crisis, which can happen at any time. Intensive care units are geared to crises. The staff has a good, if not perfect resuscitation technique and the necessary equipment is available so that the patient has the best chance of surviving the crisis. Resuscitative measures are not always successful and the nurse must not blame herself if she has done everything to the best of her ability and knowledge.

\section{Communication}

Good communication is a further factor in the nurses' well-being. Open communication should exist - the staff needs to talk to each other to alleviate anger and anxiety and thus restore inner equilibrium. This requires a sister-in-charge who is a leader and who can control the inevitable ups and downs of the staff.

The nurses need to talk to someone about their work - their doubts, their problems and their successes. They need someone to listen, who will understand and who understands better than the sisterin-charge.

The ideal situation would be regular group meetings with the same leader, so that direct communication can take place. The staff should be able to tell each other their faults and help each other to correct them. This is unfortunately very difficult as misunderstanding and victimisation may develop in such groups.

Nurses must help each other and therefore allow colleagues to express their fears and emotions. Time must be taken to listen without being judgemental, words of encouragement and positive reinforcement must be given.

Not only does good communication lead to smooth working relationships amongst nursing staff, good working relations must also exist between nurses and doctors and all paramedical staff. The doctors and nurses, in particular, must understand each other, know what is expected of them and be able to discuss problems.

\section{Group pressure}

Group pressure is also a force in the unit and it is very difficult for one person to go against the others. The individual must not be too different from the group. If a sister is pleasant to a patient, this is often seen as unnecessary and a waste of time by the group. They will be uncomplimentary about her behaviour to the patient and she will eventually stop being pleasant. If she does not comply, a new sister can easily be ostracised or excluded from the company of the others. Unfortunately this provides an incentive for nurses to conform to the pattern of behaviour of colleagues.

Another aspect in this regard is that the newcomer must know the rules and regulations of the group to be able to conform. It is thus the duty of colleagues to inform the new person of the routine. Group pressure can make a person very anxious and thus change behaviour.

\section{Aspects of patient care}

In dealing with the patients the nurse faces the dilemma of being firm and objective or warm and sympathetic. The ideal is to be empathetic - warm and understanding, but firm, thus doing what is good for the patient with the least pain or discomfort to him. The patient must also be allowed to be independent and to do as much as possible for himself. It is easier to let the patient become dependent on the nurse, because she works quicker, but the patient must not lose his independence totally.

With patients in the intensive care unit being critically ill it is understandable that the death rate is high and the staff faces death frequently. According to Koumans (1968) the death rate in intensive care units is $36 \%$. If the staff is emotionally involved with patients it becomes even more difficult to face death so often. The staff must keep this aspect in perspective by 
remembering that they are performing a useful and productive function, without which the death rate would be even higher.

Is there such a thing as a difficult patient? Not really - nurses make patients difficult. Patients are individuals and have their own fads and fancies. Nurses become irritated with patients who disagree with them and try to eradicate the patient's difficult behaviour. This upsets the patient and he will demand extra attention and become more difficult to handle. Thus it is a clash of views and moods between staff and patients which results in awkward relationships leading to a patient being labelled as difficult.

Patients often have a post-operative period of complete apathy and fatigue, indifference to fate, and respond in monosyllabi only. This disappears in a few days and is replaced by mild depression. The staff must understand this reaction and support the patient during this period, rather than believing that he is being difficult by just lying there and not responding. The staff can contribute by doing things for the patient before he asks for it or by complying with his wishes.

\section{Visitors}

A further point of harassment to the staff are the visitors. Relatives are allowed to visit at any time and they demand attention from the nurse for reassurance about the patient's condition or for explanations. They require special attention because it is their mother or son who is ill. Supporting relatives becomes even more difficult when the patient has died and the nurse must divide her attention between the other sick patients and the relatives.

\section{CONCLUSION}

The quality of patient care and the outcome of illness depends on the people providing the care - their efficiency, psychological state and technical expertise. Good working conditions and harmonious staff re- lations not only benefit the patient, but also the staff.

Any problems, no matter how minor, must be identified, the facts analysed, the cause determined and a plan of action decided upon. The problem solving process is thus also applicable to psychological aspects, where it is very important because the problems are not always clearly indentifiable.

\section{BIBLIOGRAPHY}

Druss, R; Kornfeld, D The survivors of cardiac arres JAMA Vol. 201 No.5 July 1967

2. Gillis $\mathrm{L}$ Human behavior in illness Faber and Faber London 1972

3. Hackett $\mathrm{T}$ et al The coronary care unit - an appraisal of its psychological hazards New Eng. J Med. Vol. 279 No.25 1968 .

4. Hayes J Intensive carc: The problem of stress Nursing Times Vol. 74 No.18 March 1978.

Keyes $\mathrm{J}$; Hofling $\mathrm{C}$ Basic psychiatric concepts in nursing J.B. Lippincott Philadelphia 1974.

6. Kornfeld D Psychiatric vicw of the intensive care unit Br. Med.J. Vol. I No.! January 1969

Koumans A Psychiatric consultation in an ICU JAMA Vol. 194 No.6 November 1968

8. McKegney $F$ The intensive care syndrome Connecticut Med. Vol. 30 No.9 September 1966.

9. Noble M Communication in the ICU - therapeutic or disturbing Nursing Oullook Vol. 27 No. 3 March 1979.

10. Strolie F Burntout - the elaboration of a concept American J. Nursing Vol. 79 No. 11 December 1979

\section{BOOK REVIEWS}

\section{BOEK RESENSIES}

\section{PROFESSIONAL DISCIPLINE IN NURSING. THEORY AND PRACTICE. \\ R.H. Pyne \\ Blackwell Scientific Publications, Oxford, 1981}

The title of the book is appropriate for the content it offers. The author - Deputy Registrar, General Council for England and Wales - presents of his extensive knowledge of the legal side of nursing practice in Great Britain.

The book is published by a well known publishing company. Its soft cover and size should ensure the lowest possible price and it is easy to handle. The general layout of the book is attractive, it has a clear table of contents, and although short, an alphabetical index is given. Headings and sub-headings clearly outline the content of the book.

The four illustrations are very useful, providing clear explanations and understanding of the abstract concepts of disciplinary matters and committee hearings. The book is well documented by the many case presentations.

Professionalism, professional discipline, registration and regulations pertaining to nursing are presented in a logical sequence. The guidelines on the practicalities of disciplinary matters in the middle of the book are most useful.

The chapter dealing with Nurses Welfare Service is. although U.K. orientated, thought provoking.

The author also points out what may be learnt from the study of disciplinary matters. A look at the future is also taken in this regard.

Two annexures give case descriptions and the decisions taken regarding each. An improvement on the book could perhaps have been if each case had been followed directly by the decisions taken, i.e. combined in one annexure.

The book is very readable.

\section{RECOMMENDATIONS}

Although the book is based on nursing in Great Britain it presents many situations that are similar to those in South Africa. No literature of this kind is to my knowledge available on the South African situation. This book is highly recommended for nursing students, basic and post-registration, as a prescribed book.

\section{A. ROBERTSSON}

